\title{
Simultaneousness of reproductive organs of sour cherry cultivars adaptable to Iranian climatic condition
}

\author{
Davarynejad, G. ${ }^{1}$, Ansari, M. ${ }^{1}$, Szabó, T. ${ }^{3}$, Tornyai, J. ${ }^{2}$, Soltész, M. ${ }^{2}$, Nyéki, J. ${ }^{2}$ \& Szabó, Z. ${ }^{2}$ \\ ${ }^{1}$ Horticultural Department, Ferdowsi University of Mashhad, Iran \\ ${ }^{2}$ Institutes for Research and Development, Debrecen University, Debrecen, Hungary \\ ${ }^{3}$ Fruit Research and Extension Institute, Úffehértó, Hungary
}

\begin{abstract}
Summary: Observations were made on simultaneousness of pollen shedding and stigma viability ratio, to clarify the phenology of reproductive organs of nine economically important sour cherry (Prunus cerasus L.) cultivars ('Érdi bőtermő', 'Debreceni bőtermő', 'Csengődi', 'Kántorjánosi 3', 'Újfehértói fürtös', 'Petri', 'Eva', 'Oblascinszka', and 'Pándy 279'). The main aim was investigation the possible influence of environmental cues in timing and development of phenophases and also responses of different cultivars to seasonal cues. Likely effects of climatic changes on phenological development patterns were also considered. Results showed important aspects of the reproductive biology of sour cherry flowers. The amplitude of the phenophase "beginning of blossoming" between cultivars did not exceed 6 days. There is a maximum 3 day difference in the blooming length of different directions in each cultivar. 'Pándy 279' showed high variability when the position of flowers changed on the tree shoots. 'Újfehértói fürtös' was stable in all four directions of the tree. The pollen shedding period and stigma viability ratio were synchronous. Pollen shedding phenomenon simultaneously occurred with the secretary activities of stigmas in all examined cultivars. Distribution of pollen shedding over the secretary activity of stigmas is almost good. In all five cultivars maximum pollen shedding occurred when the temperature was high during the day. In general the results of this experiment and our previous studies clearly demonstrate that the Pándy groups not recommended for plantation in new orchards of Iran.
\end{abstract}

Keywords: Phenology, sour cherry cultivars, microphenology, pollen shedding, stigma viability

\section{Introduction}

Phenological patterns are highly variable, because other factors except for weather and climate, such as genetics and age of the plant, photoperiod response, soil condition, pests, diseases, and competition with other plants influence the phenology of reproductive organs of flowers. In botany phenology refers to the timing of flower emergence, sequence of bloom, fruiting, and leaf drop in autumn. Phenology provides not only insights into how plant growth can be changed by variable conditions, but also possible outcomes of management options. These examples highlight the importance of woody plant phenology, not only as an indicator of plant responses to environmental conditions, but also in terms of economical fruit production (Sekhwela and Yates, 2007). There have been detailed studies on the triggers of phenological development in different vegetation types of woody plants (Shackleton, 1999; Van Rooyen et al., 1986, Childes, 1989, Huang et al 2006,). Flowering microphenology is an aspect of flowering phenology which refers to the viability of reproductive organs of flowers (Davarynejad et al., 1993). Blooming phenology information facilitates the choice of polliniser varieties for the plantation of any auto-incompatible or partially self fertile varieties in order to achieve maximum fruit set under most relatively unfavorable weather conditions. Air temperature has a direct influence on the flowers during blooming raises. An increase in air temperature can have opposite effects on different floral organs. While causing an increase on the growth rate of the pollen tube, warm air temperature also accelerates the rate of decline of the embryo sac (Eaton, 1959).

Steve (2002) believes that, phenology is the study of the annual cycles of plants and how they respond to seasonal changes in their environment. Similar observations on the pollination biology where climatic condition in flowering time was related to the decreasing or increasing of fruit set and fruit development (Washitani et al. 1994; Lehtila and Syrjanen 1995; Matsumura and Washitani 2000; Brys et al. 2004; Soltész et al 2004) has been studied.

Phenological patterns of flowers have been observed in some fruit cultivars, (Davarynejad et al. 1993, apple, Davarynejad et al 1996, pear, Hrotkó 1985, Prunus mahaleb, Davarynejad et al 2007, sour cherry). According to Nyéki et al (2008) sour cherries have a very short period of effective pollination period. Pollination ought to ensure within one or maximum two days after the opening of flowers. There seem to be no studies on microphenological patterns of flowers of the above mentioned sour cherry cultivars. However, similar studies have been done by Ansari and Davarynejad (2008) on three Hungarian sour cherry cultivars ('Érdi bőtermő', 'Érdi jubileum' and 'Cigány meggy') which were grown in 
climatic conditions of Iran. They showed the side effects of the fluctuations weather factors such as temperature and humidity on the reproductive organs behavior of flowers like pollen shedding and secretory activity of stigmas.

In this study, phenological development of five economically important sour cherry cultivars has been studied within the Hungarian climatic conditions. The main aim was to investigate how possible microclimatic cues influence the timing and anthesis of anthers or pollen shedding periods and stigma viability of sour cherry flowers and choosing the different cultivars combination for better pollination in new orchards of Iran.

\section{Materials and methods}

The study was carried out at the fruit Research and Education Center, Újfehértó, Eastern part of Hungary ( $47^{\circ}$ $47^{\prime} 60 \mathrm{~N}$ and $21^{\circ} 40^{\prime} 60 \mathrm{E}$, at an altitude of 403 feet), the mean annual temperature is $9.5^{\circ} \mathrm{C}$, and the annual rainfall over 50 years was $584 \mathrm{~mm}$. In general the flowering time of fruits is partially rainy and the pollination period occurs in rainy weather. Winds are predominantly from the eastnortheast.

The climate in the days of observation was cool; foggy days alternated with sunny days. The humidity at the study site ranged from $45 \%$ in the morning to about $85 \%$ for most of the day. Meteorological stations were established at the site and ran continuously throughout the study period, Atmospheric temperature; relative humidity and wind speed were recorded at every hour intervals. Day length was derived from solar radiation measurements using first morning and last evening readings above zero as sunrise and sunset, respectively. The main soils of the areas are sandy loam. The trees were grafted on Prunus mahaleb rootstock and planted in 1991, $3 \mathrm{~m}$ apart in rows that were $6 \mathrm{~m}$ apart.

Observations of blooming dynamic were followed every day at the same time (between 10 and $12 \mathrm{AM}$ ) on flowers distributed to the four quarters of the heavens on the end of branches and five tree of each cultivar with 4 branches selected, a sample comprising 100-500 flowers per branches with the beginning of bloom, The number of flowers according to their stage of development from the bud phase, opening and petal shedding was registered.

The flowering index (Index-V) was calculated according to the formula originally described by Máthé (1977) and Máthé et al. 1993:

$$
(\text { Index-V) }=(\mathrm{t}-\mathrm{b}) /(\mathrm{b}+\mathrm{v}+\mathrm{t})
$$

Where $\mathrm{b}=$ number of buds, $\mathrm{v}=$ number of flowers at anthesis and $\mathrm{t}=$ number of flowers at a post-anthesis stage (at the end of flowering).

Microphenological observations started at 7 in the mornings and carried out until 7 in the afternoons for the duration of the flowering time. The floral biology was monitored in detail of each cultivar, revealing details, such as morphological changes, flowering period, flower lifespan, anther dehiscence, nectar secretion of stigma surfaces and stigmatic status (the color variation of stigma, color varies from pale green to deep brown). The floral parts were studied by using a hand lens. To determine the positioning of stigmas and anthers within the flower, 12 flowers in the East, West, North and South directions were randomly chosen using a randomization completely block design (RCBD) with 3 replications and tagged to be studied. The phenophases of flowering were taken under consideration by using Index-V which designed for the characterization of the course of flowering (including the flowering dynamics). All the data were analyzed statistically for any relationship between plant attributes and monitored climatic variables using Excel statistic program.

\section{Results}

Synchronous activities of reproductive organs of pollen donor and pollen receiver cultivars are main preconditions for optimal pollination. Table 1 shows the length of flower phenophases of sour cherry cultivars. There is maximum 3 days difference (Pándy 279) in blooming length of different direction in each cultivar. In fact, Pándy 279 sour cherry showed high variability when the position of flowers changed on the tree shoots. Újfehértói fürtös sour cherry was stable in all four directions.

The length of flower phenophases is determined by the meteorological parameters like temperature, precipitation and radiation. As different directions of tree shoots may receive variable content of weather parameters like temperature and radiation, probable differences between directions might be seen. The amplitude of the phenophase "beginning of blossoming" between cultivars did not exceed 6 days.

Sour cherry belongs to the group of medium earlyblooming fruit trees, but it is the latest among the stone fruits. Most of the examined sour cherries in this experiment belong to the late blooming group ('Pándy $279^{\text {', ' }}$ 'Debreceni bőtermő', 'Kántorjánosi 3' and 'Oblascinszka') according to 5 group system.

Focusing on the length of flowering phenophases, it could be deducted that late blooming cultivars like 'Pándy 279' which belongs to late blooming group (Nyéki et al. 2003), showed a longer flowering duration (Table 1) in comparison with early or medium early blooming ones like 'Csengődi' which belongs to medium early group.

Reviewing the blooming process of examined sour cherry varieties showed rather irregular distribution of main blooming period of cultivars in north direction in comparison with other 3 directions (Figure 1). According to Nyéki (1989), studying the overlap of main blooming period (when more than $75 \%$ of flowers were open) could give important information's on blooming groups of cultivars which are under various climates and could play an important role to choose proper polliniser for target varieties. 
Table 1. Length of flowering phenophases of sour cherry cultivars

\begin{tabular}{|c|c|c|c|c|c|}
\hline Cultivar $\quad$ Direction & North & South & East & West & Average \\
\hline \multicolumn{6}{|c|}{ Length of flowering phenophases (days) } \\
\hline Érdi bốtermố & 14 & 14 & 13 & 12 & 13.25 \\
\hline Debreceni bốtermố & 13 & 13 & 11 & 12 & 12.25 \\
\hline Kántorjánosi 3 & 13 & 13 & 14 & 13 & 13.25 \\
\hline Éva & 14 & 14 & 14 & 13 & 13.75 \\
\hline Petri & 13 & 13 & 14 & 14 & 13.5 \\
\hline Újfehértói fürtös & 13 & 13 & 13 & 13 & 13 \\
\hline Csengódi & 10 & 10 & 12 & 12 & 11 \\
\hline Pándy 279 & 16 & 15 & 14 & 13 & 14.5 \\
\hline Oblacsinszka & 14 & 14 & 15 & 13 & 14 \\
\hline
\end{tabular}

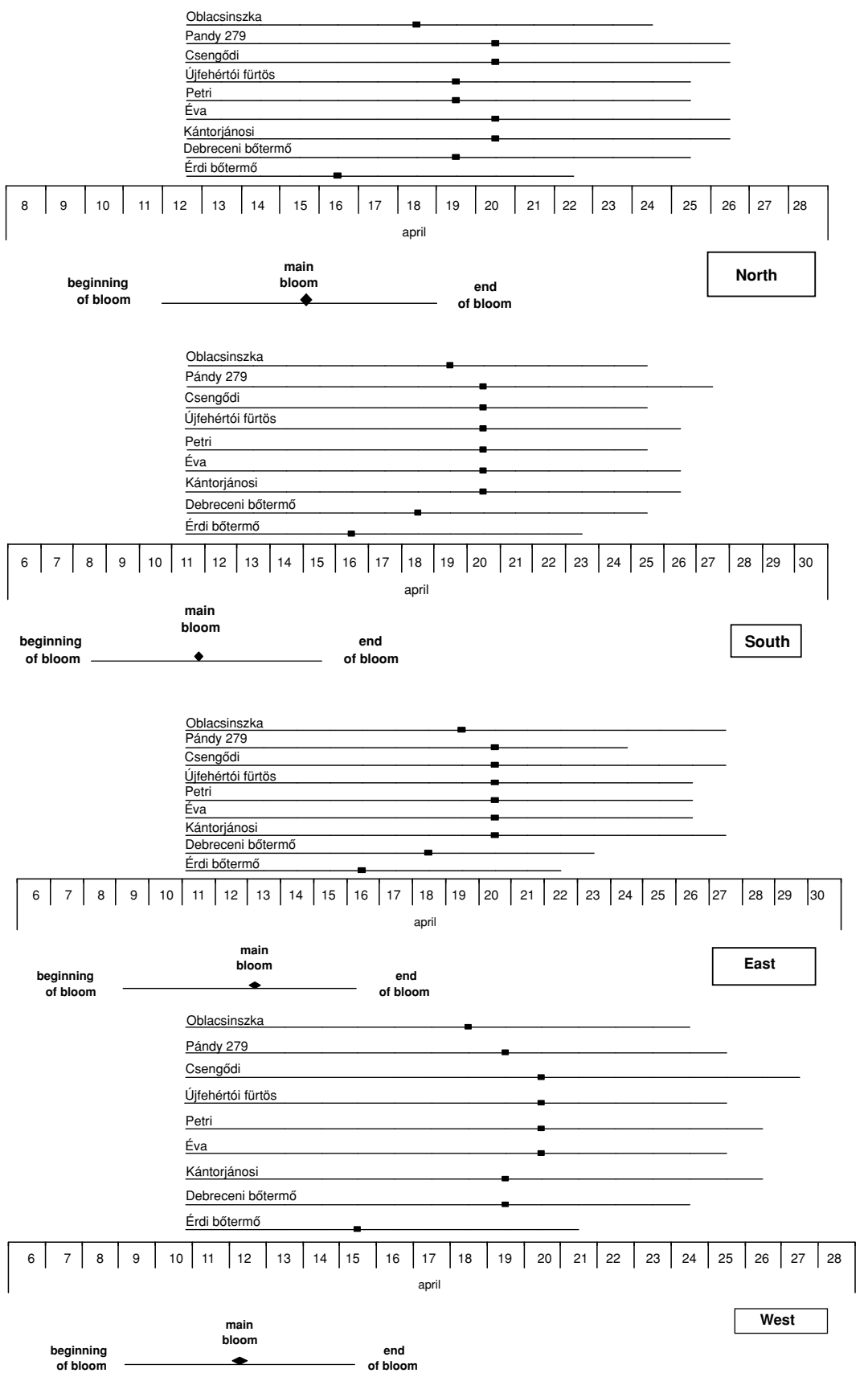

Figure 1. The blooming process of sour cherry cultivars (Hungary 2008)
Among examined cultivars, 'Pándy 279' which is self-incompatible showed more diversity than the others, from the viewpoint of main blooming period and this cultivar is mutually inter-incompatible with its cogrouped cultivars ('Debreceni bőtermo", 'Kántorjánosi 3' and 'Oblacsinszka').

'Oblacsinszka' cultivar which is in the same group with 'Pándy 279', showed 1-2 days difference in the main blooming period. Totally, the self incompatible varieties (e.g. types of the Pándy group) are unsafe yielders and should consider appropriate pollinisers which are synchronous with them.

Flowering is a phenotypic related process which environmental factors like temperature, radiation, humidity etc. in addition to genotypic cues, have considerable effects on the progressive procedure of blooming up to the fruit set. So, collation of fruit tree blooming under different environmental situations could disclose the unknown effects of environment on the process of blooming.

In 1993, Máthé et al. developed a flowering index suitable for the characterization of the course of flowering (including the flowering dynamics) of apple which called Index-V. Figure 2 shows the values of $\mathrm{V}$ - indices for all sour cherry cultivars in four directions of tree branches.

V-Indices results (Figure 2) illustrated that 'Érdi bőtermő' started to bloom two days earlier than other varieties $\left(10^{\text {th }}\right.$ of April in north and $9^{\text {th }}$ in the rest of east, west and south directions) which could not be remarkable from the viewpoint of flowering overlap with other cultivars. Results of Ansari and Davarynejad (2008) during 2005 and 2006 showed that "Érdi bőtermo"' sour cherry cultivar is also an early blooming cultivar under Iran climatic conditions too. On that experiment 'Érdi bőtermő' cultivar started to bloom at $10^{\text {th }}$ and $4^{\text {th }}$ of April respectively 
during 2005 and 2006 which shows the effect of environmental conditions on the blooming time of varieties under different climatically conditions.

Average duration of four sides flowering period showed the minimum flowering period in 'Csengödi' cultivar which lasted 11 days from the beginning of the blooming (Table 1). Duration of flowering period in 'Pándy 279 ' cultivar was the highest (14.5 days) among the cultivars which show the most diversity in the length of flowering period. Totally, four side branches selected for observations did not show differences in duration and time of flowering except north side flowers showed some irregularity in the time of main bloom in comparison with other sides (Figure 1).

\section{Microphenology of flowering}

According to Davarynejad (1993) Phenology in the case of flowers refers to the viability of reproductive organs of flowers which can be called microphenology of flowers. There is not enough information on microphenology of flowering of fruit trees which could be useful in gathering precise biography of subsequence distribution of different flowering stages which are applicable for defining suitable pollinisers and optimized time of putting beehives in the field. Before discussing the receptivity of flowers, it is worth mentioning that the flowering period is variable and temperature related. Ansari and Davarynejad (2008) applied
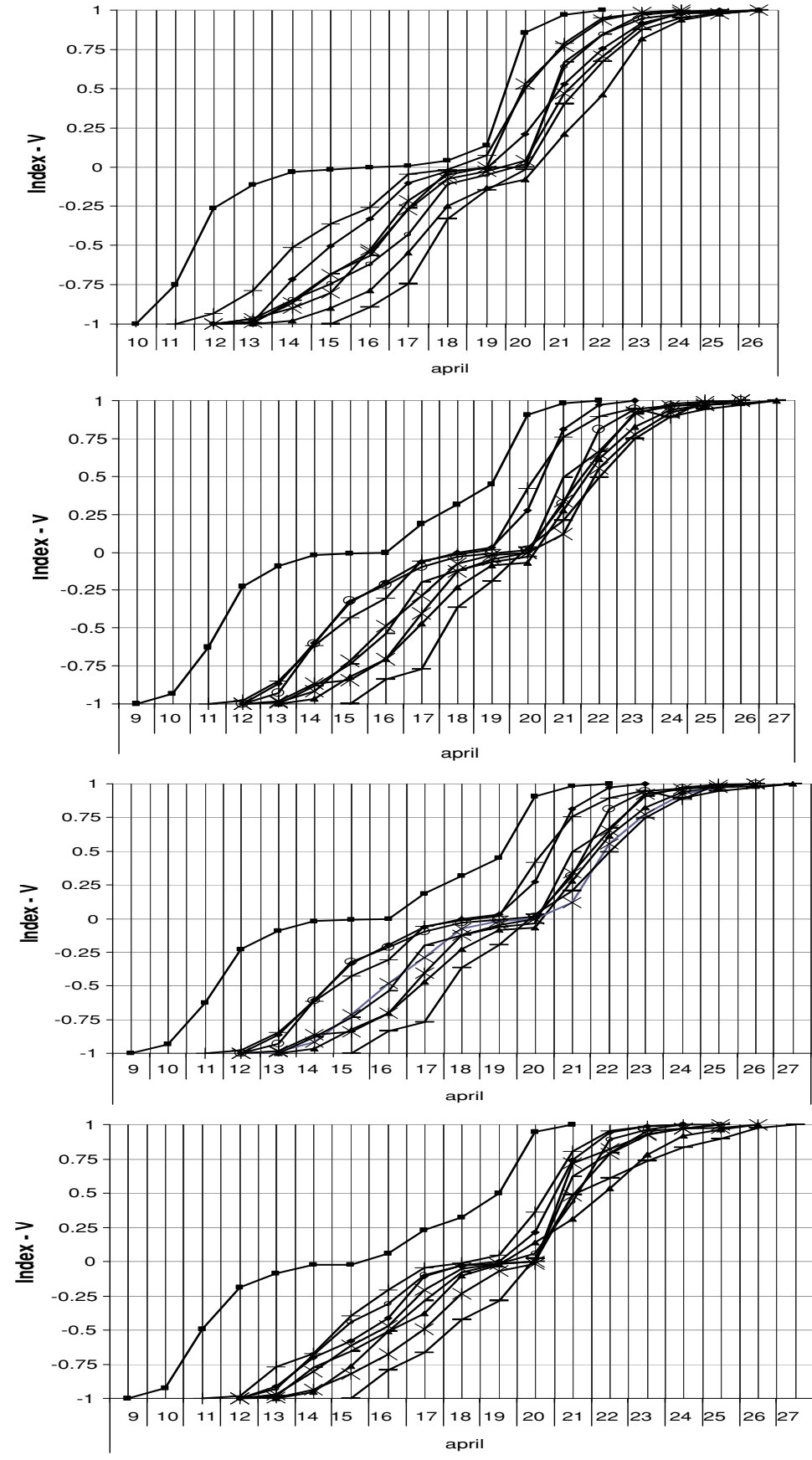

Figure 2. The V- indices of sour cherry cultivars (Hungary, 2008).

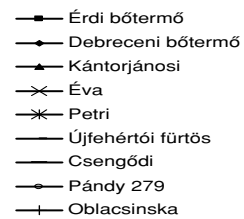

North

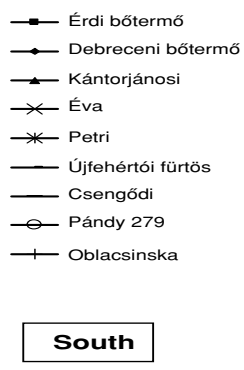

- Érdi bőtermó

——Debreceni bötermó

—— Kántorjánosi

$\times$ Éva

$\rightarrow$ Petri

— Újfehértói fürtös

Csengódi

๑ Pándy 279

— Oblacsinska
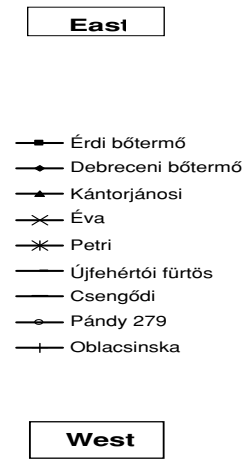

—— Debreceni bő́termó

jánosi

- Újfehértói fürtös

- Csengốd

West 
similar experiment on 3 Hungarian sour cherry cultivars ('Érdi bőtermö", Érdi jubileum and Cigány meggy) under Iran climatic conditions. Results of this experiment follow out the conclusions of that experiment.

On that experiment microphenological stages of flowering of sour cherries including 'Érdi bőtermö' were taken with consideration climatic conditions of Iran. Although pollen shedding occurred in the range of stigma viability, the overlap of the two phenomena was not good. Overcast weather condition under Iran climatic conditions caused irregular distribution of pollen shedding in the range of 'Érdi bőtermo"' secretory activity of stigma in comparison with present experiment which 'Érdi bőtermö" shows normal behavior of reproductive organs activities. During the days of present experiment we don't have rainfall. As Figure 3 illustrates, pollen shedding phenomenon occurred in the range limitation of secretory activity of stigmas in all five varieties. Distribution of pollen shedding over the secretory activity of stigmas is almost good.
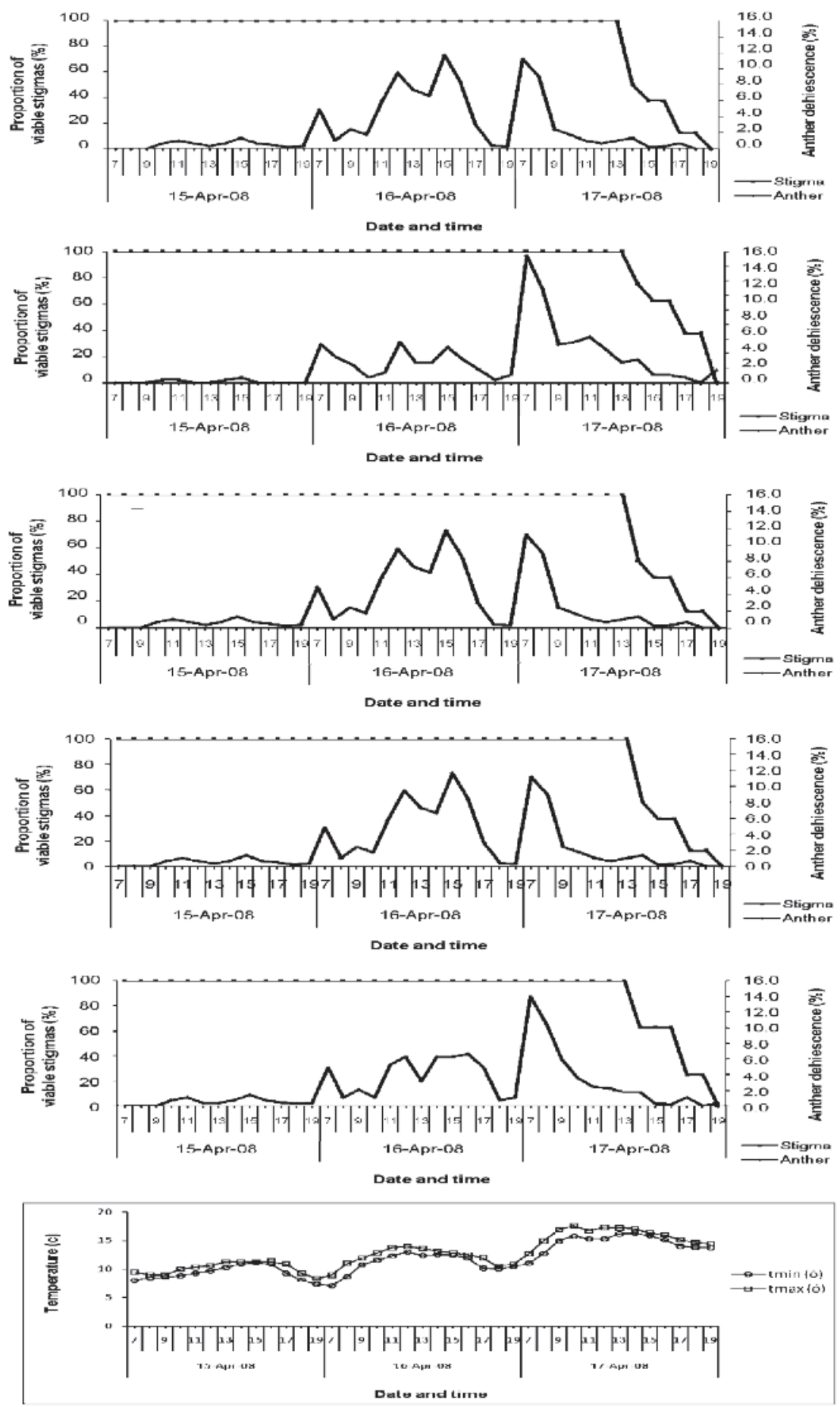

Figure 3. Reproductive organ activity of Hungarian sour cherry cultivars 
Table 2. Characteristic features of flower microphenology in four directions of the tree

\begin{tabular}{|c|c|c|c|c|c|c|}
\hline \multirow{2}{*}{ Characteristic } & \multirow{2}{*}{ Direction } & & & Cultivars & & \\
\hline & & 'Érdi bőtermö' & 'Debreceni bőtermő' & 'Eva' & 'Petri' & 'Újfehértói fürtös' \\
\hline $\begin{array}{l}\text { Duration of stigma } \\
\text { viability }\end{array}$ & $\begin{array}{c}\text { East } \\
\text { North } \\
\text { West } \\
\text { South }\end{array}$ & $\begin{array}{c}54.00 \mathrm{~B} \\
55.00 \mathrm{AB} \\
58.00 \mathrm{~A} \\
57.67 \mathrm{AB}\end{array}$ & $\begin{array}{c}54.67 \mathrm{~B} \\
60.00 \mathrm{~A} \\
58.00 \mathrm{AB} \\
57.00 \mathrm{AB}\end{array}$ & $\begin{array}{c}53.33 \mathrm{~B} \\
55.33 \mathrm{AB} \\
57.63 \mathrm{AB} \\
58.67 \mathrm{~A}\end{array}$ & $\begin{array}{l}54.33 \mathrm{~A} \\
55.00 \mathrm{~A} \\
58.00 \mathrm{~A} \\
58.00 \mathrm{~A}\end{array}$ & $\begin{array}{l}55.00 \mathrm{~A} \\
57.00 \mathrm{~A} \\
58.00 \mathrm{~A} \\
57.67 \mathrm{~A}\end{array}$ \\
\hline $\begin{array}{l}\text { Opening of the } \\
\text { first anther }\end{array}$ & $\begin{array}{c}\text { East } \\
\text { North } \\
\text { West } \\
\text { South }\end{array}$ & $\begin{array}{c}2.67 \mathrm{~B} \\
7.00 \mathrm{AB} \\
7.67 \mathrm{AB} \\
10.00 \mathrm{~A}\end{array}$ & $\begin{array}{c}26.00 \mathrm{~A} \\
26.00 \mathrm{~A} \\
8.00 \mathrm{~B} \\
5.00 \mathrm{~B}\end{array}$ & $\begin{array}{c}2.67 \mathrm{~B} \\
7.00 \mathrm{AB} \\
8.00 \mathrm{~A} \\
8.00 \mathrm{~A}\end{array}$ & $\begin{array}{c}2.33 \mathrm{~B} \\
7.00 \mathrm{AB} \\
8.00 \mathrm{AB} \\
8.67 \mathrm{~A}\end{array}$ & $\begin{array}{c}2.67 \mathrm{~B} \\
7.00 \mathrm{AB} \\
8.00 \mathrm{~A} \\
7.33 \mathrm{~A}\end{array}$ \\
\hline $\begin{array}{l}\text { Duration of anther } \\
\text { dehiscence }\end{array}$ & $\begin{array}{c}\text { East } \\
\text { North } \\
\text { West } \\
\text { South }\end{array}$ & $\begin{array}{l}49.00 \mathrm{~A} \\
45.00 \mathrm{~A} \\
49.00 \mathrm{~A} \\
38.67 \mathrm{~A}\end{array}$ & $\begin{array}{l}25.33 \mathrm{C} \\
32.33 \mathrm{~B} \\
49.00 \mathrm{~A} \\
48.00 \mathrm{~A}\end{array}$ & $\begin{array}{l}52.00 \mathrm{~A} \\
48.33 \mathrm{~A} \\
49.67 \mathrm{~A} \\
44.33 \mathrm{~A}\end{array}$ & $\begin{array}{l}39.67 \mathrm{~A} \\
45.00 \mathrm{~A} \\
49.00 \mathrm{~A} \\
39.33 \mathrm{~A}\end{array}$ & $\begin{array}{c}49.00 \mathrm{~A} \\
46.00 \\
49.00 \\
37.67 \mathrm{~A}\end{array}$ \\
\hline
\end{tabular}

Averages with the same letters in each column are not significantly different in LSD $=0.05$

In all five cultivars maximum pollen shedding occurred about the high temperature part of the day. Pollen shedding is naturally a mechanical phenomenon and affected by environmental factors. In all five cultivars, pollen shedding started only after flower opening.

Table 2 shows the importance of direction on the characteristic features of flowers microphenology of examined cultivars. Duration of stigma viability (existence of secretions on the stigma surface) is a key factor to verify the fertilization of flowers. As Table 2 shows 'Petri' and 'Újfehértói fürtös' cultivars do not show significant differences in duration of stigma viability in four main directions. In 'Eva', 'Debreceni bőtermö' and 'Érdi bőtermö' cultivars, South, North and West directions showed highest duration of stigma viability respectively in comparison with other directions. In fact, results of four directions were conflicting.

Contradictory results of time between openings of flowers to dehiscence of first anther are shown in Table 2. Except 'Debreceni bőtermo" cultivar, results of duration of anther dehiscence in four directions of other cultivars were not significantly different (Table 2). Totally, results of characteristic features of flower microphenology were inconsistent.

\section{Conclusion}

Focusing on the length of flowering phenophases could be deducted that late blooming cultivars like 'Pándy $279^{\circ}$ which belongs to late blooming group, showed a longer flowering duration in comparison with early or medium early blooming ones like 'Csengödi' which belongs to medium early group. Most of the examined sour cherries in this experiment belong to the late blooming group ('Pándy 279', 'Debreceni bőtermö', 'Kántorjánosi $3^{\text {' }}$ and 'Oblascinszka') according to 5 group system.

In fact, 'Pándy 279 ' sour cherry showed high variability when the position of flowers changed on the tree shoots. 'Újfehértói fürtös' sour cherry was stable in all four directions. Among examined varieties, 'Pándy $279^{\circ}$ which is self incompatible showed more diversity than other varieties from the viewpoint of main blooming period and is mutually inter-incompatible with its co-grouped cultivars ('Debreceni bőtermő', 'Kántorjánosi 3' and 'Oblascinszka').

'Oblascinszka' cultivar which is in the same group with 'Pándy 279' sour cherry showed 1-2 days difference in main blooming period. Totally, the self-incompatible varieties (e.g. types of the Pándy group) are unsafe yielders and should consider appropriate polliniser which are synchronous with them. In General on the basis of the results of this experiment and our previous studies (Ansari and Davarynejad, 2008) and the achieved results by Nyéki et al. (2003) the Pándy group not recommended for Iranian new orchards.

Acknowledgment: We gratefully thank Ferdowsi University of Mashhad, for supporting this work by the grants Project.

\section{References}

Ansari, M. \& Davarynejad, G.H. (2008): The Flower Phenology of Sour Cherry Cultivars, American-Eurasian J. Agric. \& Environ. Sci., 4 (1): 117-124.

Brys, R., Jacquemyn H., Endels P., van Rossum F., Hermy M., Triest W., De Bruyn L. \& Blust, G.D.E. (2004): Reduced reproductive success in small populations of the self-incompatible Primula vulgaris. J. Ecol., 92: 5-14.

Childes, S.L. (1989): Phenology of nine common woody species in semi-arid deciduous Kalahari sand vegetation. Vegetatio, 79, 151-163.

Davarynejad, G.H. (1996): Microphenology of flower of pear cultivars. Acta Horticulture, 441

Davarynejad, G.H., Nyéki, J. Blust \& Z. Szabó. (1993): Microphonology of flowering in two apple cultivars, Acta Agronomica Hungarica, 42 (3-4): 365-375.

Davarynejad, G.H., Szabó, Z., Nyéki, J., Blust \& Ansari, M. (2007): Flower microphenology of Hungarian sour cherry cultivars in Iran climatical conditions. International Journal of Horticultural Science, 13 (3): 99-101. 
Eaton, G.W. (1959): A study of the megagametophyte in Prunus avium and its relation to fruit setting. Can. J. Plant. Sci. 39 (4): 466-476.

Hrotkó, K. (1985): A sajmeggy (Cerasus mahaleb/L/Mill.) klónok virágzási ideje. Kertészeti Egyetem Közleményei, Budapest, 47: 21-23.

Huang, Y., Zhang, C.-Q., Blackmore, S. \& Wu1, Z.-K. (2006): A preliminary study on pollination biology of Omphalogramma souliei Franch. (Primulaceae), a species endemic to China Plant systematic and evolution, 261: 89-98.

Lehtila, K. \& Syrjanen, K. (1995): Positive effects of pollination on subsequent size, reproduction, and survival of Primula veris. Ecology, 76 (4):1084-1098.

Máthé, A, Davarynejad, G.H. \& Nyéki,J. (1993): Comparison of 12 apple varieties by the application of Index of flowering, Acta Agronomica Hungarica, Vol. 42 (1-2): 23-30.

Máthé, A. (1977): Az Adonis vernalis viragzasanak szamszeru kifejezese (Numerical expression of the flowering Adonis vernalis L.). Herba Hung., 16 (2): 35-47.

Matsumura, C. \& Washitani, I. (2000): Effects of population size and pollinator limitation on seed-set of Primula sieboldii populations in a fragmented landscape. Ecol. Res., 15: 307-322.

Nyéki, J. (1989): Csonthéjas gyümölcsűek virágzása és termékenyülése. Thesis. MTA, Budapest.

Nyéki, J. Soltész M. \& Szabó, Z. (2008): Morphology, Biology and fertility of flowers in temperate zone fruits. Academic Publisher, Budapest, pp 450
Nyéki, J., Szabó T. \& Szabó, Z. (2002): Blooming phenology and fertility of sour cherry cultivars selected in Hungary. International Journal of Horticultural Science, 8 (2): 33-37.

Racskó, J., Nyéki, J., Soltész, M. \& Szabó Z. (2007): Floral biology, pollination and fertilization of temperate zone fruit trees. International Journal of Horticultural Science, 13 (3): 7-12.

Sekhwela, M.B.M. \& Yates, D.J. (2007): A phenological study of dominant acacia tree species in areas with different rainfall regimes in the Kalahari of Botswana. Journal of Arid Environments, 70: $1-17$.

Shackleton, C.M. (1999): Rainfall and topo-edaphic influence on woody community phenology in South African savannas. Global Ecology and Biogeography, 8: 125-136.

Soltész, M., Nyéki, J. \& Szabó Z. (2004): A klimaváltozás kihívásai a gyümölcstermesztésben., Agro-21 Füzetek, 34: 3-20.

Steve, D. (2002): Phenology Web Links: (1) Sequence of Bloom, Floral Calendars, What's in Bloom; (2) Birds, Bees, Insects and Weeds

Szabó, Z. (1989): Europai es japan szilvafajtak viragzasa, termekyulese, tarsitasa. Thesis. MTA, Budapest

Van Rooyen, N., Theron, G.K. \& Grobbelaar, N. (1986): The vegetation of the Roodeplaat Dam nature reserve: IV. Phenology and climate. South African Journal of Botany, 52: 159-166.

Washitani, I., Ryo O., Hyoji N. \& Masaru, N. (1994): Patterns of female fertility in heterostylous Primula sieboldii under severe pollinator limitation. J. Ecol., 82: 571-579. 